\title{
Long-term flow rates and biomat zone hydrology in soil columns receiving septic tank effluent
}

\author{
C.D Beal $^{\mathrm{a}}$ *, E.A Gardner ${ }^{\mathrm{b}}$, G. Kirchhof ${ }^{\mathrm{c}}$, N. W. Menzies ${ }^{\mathrm{c}}$ \\ ${ }^{a}$ School of Land \& Food Sciences, The University of Queensland, and Coastal CRC, Brisbane, \\ Australia \\ ${ }^{b}$ Qld Department of Natural Resources \& Mines and Coastal CRC, Brisbane, Australia \\ ${ }^{c}$ School of Land \& Food Sciences, The University of Queensland, Brisbane, Australia \\ * Corresponding author. Tel.: 61-7-3346 9149; fax: 61-7-3365 1177; email address: \\ c.beal@uq.edu.au
}

\begin{abstract}
Soil absorption systems (SAS) are used commonly to treat and disperse septic tank effluent (STE). SAS can hydraulically fail as a result of the low permeable biomat zone that develops on the infiltrative surface. The objectives of this experiment were to compare the hydraulic properties of biomats grown in soils of different textures, to investigate the long-term acceptance rates (LTAR) from prolonged application of STE, and to assess if soils were of major important in determining LTAR. The STE was applied to repacked sand, Oxisol and Vertisol soil columns over a period of 16 months, at equivalent hydraulic loading rates of 50,35 and $8 \mathrm{~L} / \mathrm{m}^{2} / \mathrm{d}$, respectively. Infiltration rates, soil matric potentials, and biomat hydraulic properties were measured either directly from the soil columns or calculated using established soil physics theory.
\end{abstract}

Biomats 1 to $2 \mathrm{~cm}$ thick developed in all soils columns with hydraulic resistances of 27 to 39 d. These biomats reduced a 4 order of magnitude variation in saturated hydraulic conductivity $\left(K_{s}\right)$ between the soils to a one order of magnitude variation in LTAR. A relationship between biomat resistance and organic loading rate was observed 
in all soils. Saturated hydraulic conductivity influenced the rate and extent of biomat development. However, once the biomat was established, the LTAR was governed by the resistance of the biomat and the sub-biomat soil unsaturated flow regime induced by the biomat. Results show that whilst initial soil $K_{s}$ is likely to be important in the establishment of the biomat zone in a trench, LTAR is determined by the biomat resistance and the unsaturated soil hydraulic conductivity, not the $K_{s}$ of a soil. The results call into question the commonly used approach of basing the LTAR, and ultimately trench length in SAS, on the initial $K_{s}$ of soils.

Keywords: LTAR, loading rates, septic system, hydraulic conductivity, biomat, wastewater, resistance

\section{Introduction}

On-site sewerage treatments, such as septic tank - soil absorption systems (SAS), are used in non-sewered areas to treat and disperse domestic wastewater. In Australia, SAS represent at least $75 \%$ of the $>1.5$ million on-site sewerage systems, and in the United States over 60 million people rely on on-site sewerage systems, of which the majority are SAS (USEPA, 2002). Primary treatment in a SAS occurs in the septic tank where settlement and anaerobic digestion processes occur (Crites and Tchobanoglous, 1998). The liquid component in the septic tank is gravity or pressure distributed into a soil absorption trench (leachfield), where secondary treatment (e.g. sorption, oxidation, biotransformation) occurs during passage through the soil. The limiting factor in the long-term performance of the SAS is the hydraulically retarding biomat zone that develops along the bottom and lower sidewalls of the trench (Siegrist and Boyle, 1987; Beal et al., 2005a). Hydraulic failure, (surface surcharging of effluent), can occur if the loading rate of effluent into the trench exceeds the infiltrative capacity of the biomat zone. The biomat zone is a heterogenous layer comprised of 
accumulated suspended solids and organic matter contained in the effluent, a large number of microorganisms and their metabolites and by-products (e.g. extracellular polysaccharides) (Kristiansen, 1981; Siegrist and Boyle, 1987; Baveye et al., 1998). Previous studies have shown that factors affecting the development of the biomat zone are primarily the hydraulic loading rate $\left(\mathrm{L} / \mathrm{m}^{2} / \mathrm{d}\right)$ the organic loading rate (i. e. cumulative 5-day biochemical oxygen demand $\left(\mathrm{BOD}_{5}\right)$, and total suspended solids (TSS)), with other important factors being the dosing regime, the aeration status of the infiltrative surface, and soil biogeochemical properties (Kropf et al., 1977; Kristiansen, 1981; Siegrist and Boyle, 1987; Stevik et al., 1999).

The infiltrative capacity of the biomat zone is directly influenced by the resistance of the biomat (a function of its thickness, $Z_{b}$, and its saturated hydraulic conductivity, $K_{b}$ ), and the sub-biomat unsaturated hydraulic properties. The biomat zone substantially reduces flow in SAS in two ways. Firstly, the low $K_{b}$ physically impedes flow, and secondly the resistance of the biomat induces an unsaturated flow regime (i.e. < soil saturated hydraulic conductivity) in the underlying soil. Some reported infiltration rates through the biomat / sub-biomat soil zone in permeable, sandy soils are 5.8 to $7.5 \mathrm{~cm} / \mathrm{d}$ (Bouma, 1975), 1.4 to $2.6 \mathrm{~cm} / \mathrm{d}$ (Kropf et al., 1977) and $\sim 2$ to $3 \mathrm{~cm} / \mathrm{d}$ (Beach et al., 2005). The low infiltration rates of these permeable soils suggest that the initial saturated hydraulic conductivity, $K_{s}$, of the soil becomes unimportant as the biomat develops and becomes the dominant regulator of downward flow into the soil.

Bouma (1975) first described the physics of flow through the biomat and the unsaturated soil layer and likened it to infiltration though a surface crusted soil (following Hillel and Gardner (1969)). The relationship assumes steady-state flow driven by a substantial hydraulic gradient 
across the biomat and a unit hydraulic gradient (flow by gravity only) in the sub-biomat nonlayered soil zone (Bouma 1975). The steady-state flow through the biomat / soil interface may be expressed quantitatively as:

$$
Q=K_{u}(\psi)=K_{b}\left(\frac{H_{o}+\psi_{u}+Z_{b}}{Z_{b}}\right)
$$

where $K_{u}$ the unsaturated soil hydraulic conductivity $(\mathrm{m} / \mathrm{d}), K_{b}$ is the biomat hydraulic conductivity $(\mathrm{m} / \mathrm{d}), H_{o}$ is ponded head above biomat $(\mathrm{m}), \Psi_{u}$ is matric potential of sub-biomat soil (-m) and $Z_{b}$ is biomat zone thickness (m), (see definition diagram in Fig. 1).

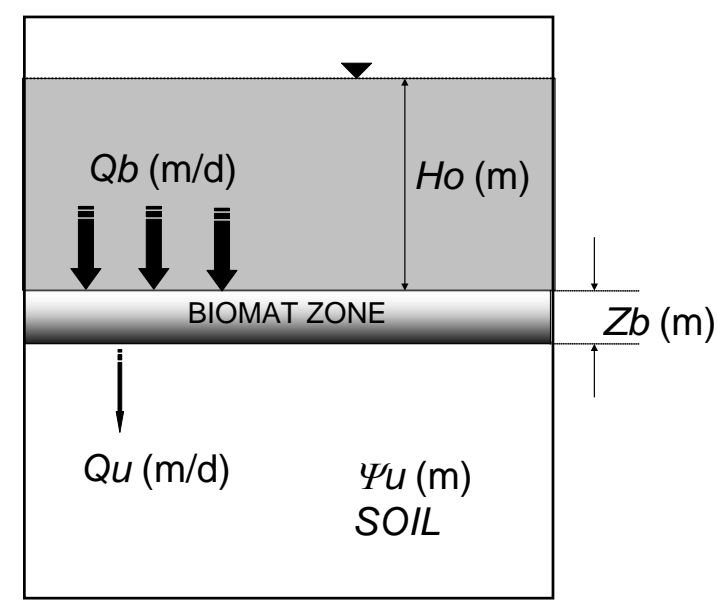

Fig. 1 Schematic representation of infiltration through the biomat zone

The resultant $Q$ is the long-term, one-dimensional acceptance rate (LTAR) at which a SAS can theoretically continue to accept effluent without hydraulic failure occurring, (i.e. trench ponding causing surcharge at soil surface). The LTAR is a key parameter used to calculate the length of trench required to ensure that they are not hydraulically overloaded (Standards 
Australia and Standards New Zealand, 2000). The LTAR is usually expressed as mm/d which is numerically equivalent to $\mathrm{L} / \mathrm{m}^{2} / \mathrm{d}$. In the United States, the Design Loading Rate (DLR) is a similar concept (USEPA, 2002). Both the LTAR and DLR parameters are based on the initial saturated hydraulic conductivity of the soil; a key assumption that this paper explores.

The hydraulic effects of the biomat zone on LTAR $(Q)$ can be predicted if the resistance of the biomat and the unsaturated hydraulic conductivity characteristics, $K(\Psi)$, of the underlying soil are known. Combining $K_{b}$ and $Z_{b}$ into the single parameter of hydraulic resistance $\left(R_{b}\right)$, and rearranging equations $1, Q$ can be written as:

$$
Q=K_{b}\left(\frac{\Delta H}{Z_{b}}\right) \text { or } \quad Q=\left(\frac{K_{b}}{Z_{b}}\right) \Delta H=\frac{\Delta H}{R_{b}}
$$

Note that the ratio $K_{b} / Z_{b}$ is the reciprocal of $R_{b}$ (Hillel and Gardner 1969). The $\Delta H$ value is the total hydraulic difference across the biomat, and is, therefore, a function of the ponded depth above and matric suction beneath the biomat, and can be defined as $H_{o}+\Psi_{u}+Z_{b}$ (Bouma 1975). The $\Delta H$ will vary between soils due to the different unsaturated hydraulic characteristics between each soil. Equation 2 can be rearranged to calculate $R_{b}$, where $Q$ is the measured steady state infiltration rate through the biomat. Equations 1 and 2 imply that both the biomat zone and underlying soil will influence the infiltration rate. This assumption is also implicit in the calculation of LTAR for trench design recommended in the current AS/NZS Standard. However, the AS/NZS Standard draws on limited scientific data to support the LTAR values 
used in trench design. Recommended LTAR values vary from $5 \mathrm{~L} / \mathrm{m}^{2} / \mathrm{d}$ to $35 \mathrm{~L} / \mathrm{m}^{2} / \mathrm{d}$, as soil texture varies from light clay to sand (Standards Australia and Standards New Zealand, 2000).

There have been many descriptions of unsaturated flow in SAS, (Laak, 1986; Siegrist et al., 2004; Beach et al., 2005), although they are all essentially based on the soil physics principles first applied by Bouma (1975). Siegrist et al. (2004) discussed the influence of surface architecture on LTAR, and demonstrated that that the soil's effluent infiltration capacity is greatly facilitated by the absence of gravel. Beach et al. (2005) also investigated this area and described the concept of effective hydraulic conductivity, $K_{e}$, which is the overall hydraulic conductivity of the infiltrative zone, including the biomat and underlying soil. A similar approach to Bouma (1975) was adopted by Beach et al. (2005) where the 'normalized hydraulic conductivity function' (essentially the reciprocal of biomat resistance) was used to describe the hydraulic conductance of the biomat zone in sand columns. They reported $K_{e}$ values which were 2 orders of magnitude lower than the initial $K_{s}$ values.

One of the main influences on LTAR is the sub-biomat unsaturated hydraulic conductivity matric potential function $(K(\Psi))$. The $K(\Psi)$ function differ between soils and is related to pore size distribution, and hence soil texture and structure. This area of SAS hydrology is poorly understood, as much of the work to date has focussed on sand media (Kristiansen, 1981; Pell and Nyberg, 1989; van Cuyk et al., 2001; Bancole et al., 2003; Beach et al., 2005). While this has yielded valuable insights into the behaviour of the soil/biomat interface, we believe there is value in exploring the interaction of soil texture and $R_{b}$ on LTAR. The objectives of this experiment were to compare the hydraulic properties of biomats grown in different soil 
textures; to investigate the evolution of LTAR from long-term application of septic tank effluent; and assess if the soil's characteristics were important in determining LTAR.

\section{Materials and methods}

\subsection{Soils}

Three soils were used in the experiment; an Oxisol (USDA and NRCS, 1996) or Red Ferrosol (Isbell, 1998) from Redland Bay, Queensland, a Vertisol (USDA and NRCS, 1996) or Grey Vertosol (Isbell, 1998) from Griffith, New South Wales, and a mined river sand from the Brisbane River. Bulk samples of the Oxisol and Vertisol were obtained by excavating the surface layer (0 to $0.2 \mathrm{~m}$ ) of each profile. The river sand was obtained from a local supplier. Some soil physical and chemical properties of each soil used in the column experiment are presented in Table 1. Saturated hydraulic conductivities of the soils were measured using the constant head method described in McKenzie et al. (2002).

\section{Table 1}

Selected properties of the repacked soils ( \pm 1 standard deviation)

\begin{tabular}{|c|c|c|c|c|c|c|c|c|c|}
\hline Soil & Texture & $\begin{array}{c}\text { Ks } \\
(\mathrm{m} / \mathrm{d})\end{array}$ & $\begin{array}{c}\text { Bulk } \\
\text { density } \\
\left(\mathrm{Mg} / \mathrm{m}^{3}\right)\end{array}$ & Porosity ${ }^{\mathrm{B}}$ & $\begin{array}{c}\text { Organic } \\
\text { carbon }^{\mathrm{c}} \\
(\%)\end{array}$ & $\mathrm{pH}^{\mathrm{D}}$ & $\begin{array}{l}\text { Sand } \\
\text { (\% of }\end{array}$ & $\begin{array}{l}\text { Silt } \\
\mathrm{mm}\end{array}$ & $\begin{array}{l}\text { Clay } \\
\text { tion }^{\mathrm{E}} \text { ) }\end{array}$ \\
\hline River sand & $\begin{array}{c}\text { coarse } \\
\text { sand }\end{array}$ & $\begin{array}{c}24.7 \\
( \pm 2.4)\end{array}$ & 1.59 & 0.40 & $<1$ & 7.7 & $>95$ & $<5$ & $<1$ \\
\hline Oxisol & $\begin{array}{c}\text { clay loam } \\
\text { (sub plastic) }\end{array}$ & $\begin{array}{c}7.3 \\
( \pm 0.32)\end{array}$ & 1.07 & 0.64 & 3.7 & 6.4 & 10 & 9 & 81 \\
\hline Vertisol & $\begin{array}{l}\text { medium - } \\
\text { heavy clay } \\
\text { (plastic) }\end{array}$ & $\begin{array}{c}0.23 \\
( \pm 0.012)\end{array}$ & 1.29 & 0.59 & 1.15 & 6.9 & 10 & 48 & 42 \\
\hline $\begin{array}{l}{ }^{\mathrm{A}} \text { obtain } \\
{ }^{\mathrm{B}} \text { porosi } \\
{ }_{\mathrm{C}} \text { total o } \\
{ }_{\mathrm{D}}^{\mathrm{D}} \mathrm{pH} \text { me }\end{array}$ & $\begin{array}{l}\text { from methods } \\
\text { ralues obtaine } \\
\text { anic carbon d } \\
\text { Ired a } 1: 5 \mathrm{~s}\end{array}$ & $\begin{array}{l}\text { escribed by } \\
\text { from meast } \\
\text { rmined by } \\
\text { :water sus }\end{array}$ & $\begin{array}{l}\text { ake and } \mathrm{H} \\
\text { saturated } \\
\text { combustic } \\
\text { sion }\end{array}$ & $\begin{array}{l}\text { ge (1986) } \\
\text { lumetric w } \\
\text { method usi }\end{array}$ & $\begin{array}{l}\text { contents } \\
\text { LECO CI }\end{array}$ & 00 ar & & & \\
\hline
\end{tabular}


The Oxisol and Vertisol samples were air-dried and ground to pass through a $2 \mathrm{~mm}$ sieve. The pressure plate method was used to obtain soil moisture retention characteristics of the sieved soils (Klute, 1986) (Fig. 2).

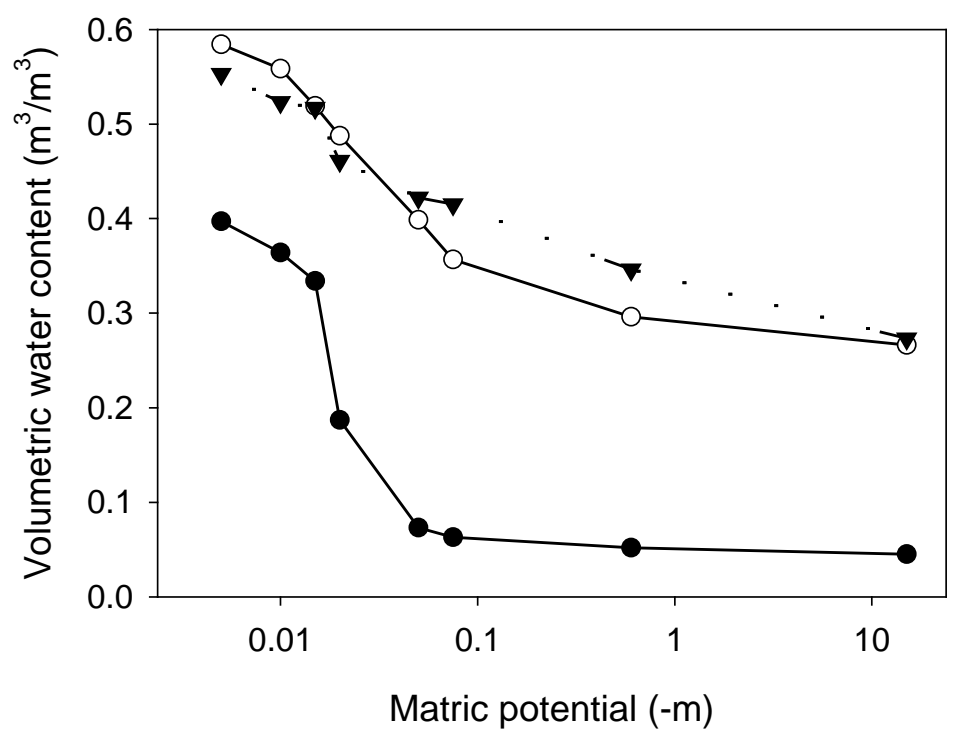

Fig. 2 Soil moisture retention characteristic curves

The use of repacked soil columns minimised uncontrolled variability between treatments that may occur in undisturbed columns, thus allowing soil texture differences to be more precisely identified. This was consistent with the objective of the experiment, to investigate the interaction of biomat resistance with soils of differing $K(\Psi)$ characteristics. The textures and clay mineralogy chosen clearly established these differences. Additionally, the soil surface along the bottom of trenches are disturbed during their installation (e.g. excavation, distribution pipe / chamber laying and gravel filling), therefore using disturbed soils to examine the biomat / soil interface would most likely represent, to a reasonable extent, field conditions within a newly constructed trench. 


\subsection{Experimental setup}

The design of the soil columns is shown in Fig. 3. Twelve PVC columns (diameter $0.15 \mathrm{~m}$, length $1.05 \mathrm{~m}$ ) were packed with the air-dried soils. There were three replicate (treatment) columns and a control column for each soil type. Soil was distributed evenly and continuously into each column to a depth of $1 \mathrm{~m}$. Columns were tapped lightly during and after packing to help settle the soil. The weight of the soil used was recorded and replicate columns were packed to represent as closely as possible the field bulk densities. Average bulk densities $\left(\mathrm{Mg} / \mathrm{m}^{3}\right)$ were $1.52( \pm 0.02)$ for the sand, $1.08( \pm 0.01)$ for the Oxisol, and $1.30( \pm 0.01)$ for the Vertisol.

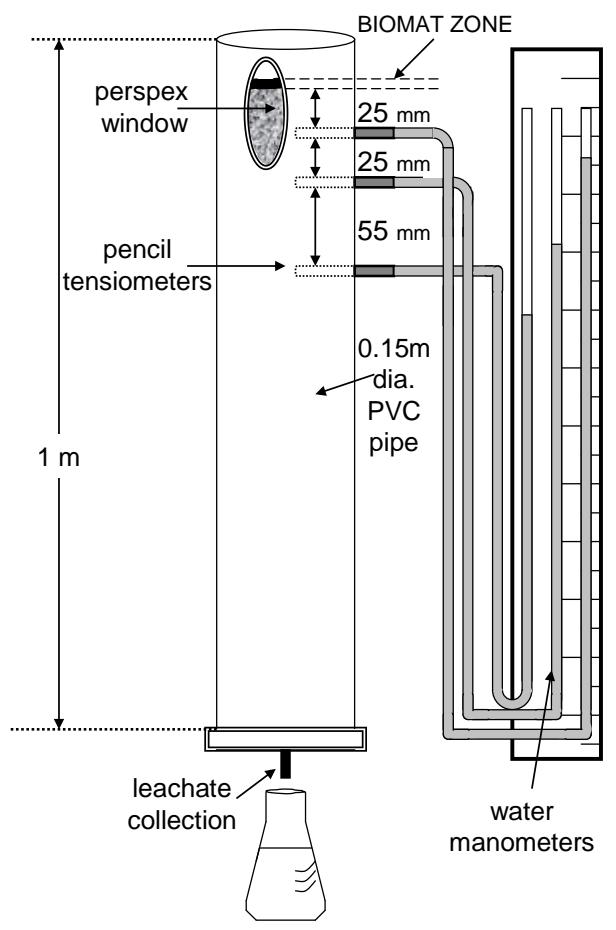

Fig. 3 Schematic diagram of soil column set-up.

A small transparent window (30 mm wide x $150 \mathrm{~mm}$ long) was installed in the upper part of each column to allow for visual observation of the biomat zone characteristics. 
A thin ( 10 mm) layer of gravel (diameter $\sim 5 \mathrm{~mm}$ ) was placed on the soil surface to minimize disturbance to the soil during effluent application. This gravel also helped to mimic the bottom layer of gravel / aggregate in contact with the soil surface of an absorption trench. The columns were located in a dark room, where a temperature range of 15 to $20^{\circ} \mathrm{C}$ was maintained.

Using a 1.5 volt DC impeller pump (16 L/minute), septic tank effluent (STE) was collected weekly from a domestic-sized septic tank $(\sim 1,500 \mathrm{~L})$, and was stored in the temperaturecontrolled laboratory in a sealed holding tank. The septic tank received blackwater (toilet waste) only and serviced a residential property (2 adults and three children) located within 20 $\mathrm{km}$ of the research laboratory. This type of system (split blackwater / greywater trenches) represents the most common SAS type currently installed in Australian soils (Jelliffe, 1994; Rawlinson, 1994; Beal et al., 2005b). Therefore, the STE used in the experiment was generally representative of the typical STE quality applied to SAS in Australia. The STE was applied daily at loading rates equivalent to $50 \mathrm{~L} / \mathrm{m}^{2} / \mathrm{d}$ (sand), $35 \mathrm{~L} / \mathrm{m}^{2} / \mathrm{d}$ (Oxisol) and $8 \mathrm{~L} / \mathrm{m}^{2} / \mathrm{d}$ (Vertisol). These rates were based on design loading rates recommended in the Australian and New Zealand Standards for SAS which relate to the soil's indicative permeability (Standards Australia and Standards New Zealand, 2000). Once ponding occurred in the columns (about 100 days), the frequency of STE application was reduced from daily to 2 to 3 times weekly, in order to maintain a ponded height of approximately $30 \mathrm{~mm}$ in all the columns. 
The inorganic composition of the STE was used to create a control solution so that a comparable cationic composition to the STE was created without the organic C content. The control columns were supplied with a solution having a sodium absorption ratio (SAR) of 1.2 and an electrical conductivity (EC) of $3.15 \mathrm{dS} / \mathrm{m}$ using $\mathrm{Ca}, \mathrm{Mg}, \mathrm{K}$ and $\mathrm{Na}$ chloride salts in deionised water. Maintaining a control solution with the same cationic composition as the STE allowed the distinction to made between reduced infiltration rate as a result of cation / clay interactions (e.g. dispersion and swelling of the clay from $\mathrm{Na}$ ion exchange) from the reduction due to biomat development. The solution was only applied to the control columns when STE was applied to the treatment columns. Solution loading rates were the same as the treatment loading rates for each soil.

The STE was characterised for a number of key parameters, including TSS, five day biochemical oxygen demand $\left(\mathrm{BOD}_{5}\right)$, total carbon (TC), dissolved organic carbon (DOC), EC, $\mathrm{pH}$, total Kjeldahl nitrogen (TKN), total phosphorus (TP), and SAR. Standard methods were used for the physical and chemical analyses of the STE (American Public Health Association, 1998). The average values for key parameters are presented in Table 2. Samples for analyses were taken at the time of STE collection.

\section{Table 2}

Average septic tank effluent compositions from 10 sampling events over approximately 16 months.

\begin{tabular}{cccccccc}
\hline & $\begin{array}{c}\mathrm{BOD}_{5} \\
\mathrm{mg} / \mathrm{L}\end{array}$ & $\begin{array}{c}\mathrm{TSS} \\
\mathrm{mg} / \mathrm{L}\end{array}$ & $\begin{array}{c}\mathrm{TP} \\
\mathrm{mg} / \mathrm{L}\end{array}$ & $\begin{array}{c}\mathrm{TKN} \\
\mathrm{mg} / \mathrm{L}\end{array}$ & $\mathrm{pH}$ & $\begin{array}{c}\mathrm{EC} \\
(\mathrm{dS} / \mathrm{m})\end{array}$ & $\mathrm{SAR}$ \\
\hline Average & 178 & 173 & 39 & 147 & 7.4 & 3.15 & 1.2 \\
$\mathrm{SD}^{\mathrm{A}}$ & 38 & 67 & 23 & 61 & 0.77 & 0.45 & 0.46 \\
\hline $\mathrm{A}$ & & & & & &
\end{tabular}

${ }^{\mathrm{A}} \mathrm{SD}- \pm 1$ standard deviation 
Nutrient concentrations in the STE were considerably higher than typical ranges reported in the Australian literature (Patterson, 1994; Gardner et al., 1997), although more recent work suggests that higher concentrations of nutrients in STE in Australia is likely to be the norm (Charles et al., 2004).

\subsection{Measurement of soil potentials and biomat properties}

Measurements of soil moisture potentials, infiltration rates and biomat properties were recorded monthly in the early stages (e. g. < 100 days), and weekly in the later stages of the experiment. Soil moisture potentials were measured using ceramic pencil tensiometers (internal diameter $8 \mathrm{~mm}$, length $100 \mathrm{~mm}$ ), inserted horizontally into columns at depths $25 \mathrm{~mm}, 50 \mathrm{~mm}$ and $105 \mathrm{~mm}$ below the biomat zone (Fig. 2). Water manometers attached to the tensiometers measured the matric potential below the biomat zone. Infiltration rates were calculated from the changes (decreases) in the ponded height above the biomat over time. The thickness of the biomat was measured through the transparent windows located at the top of the columns (Fig. 2). Following Bouma (1975), $R_{b}$ was calculated using $\Psi_{25 \mathrm{~mm}}, \mathrm{H}_{0}$ and infiltration rate for as described in Equation 2. The value of $K_{b}$ was determined by dividing each data pair of $Z_{b}$ and $R_{b}$. Campbell's (1974) model was used to calculate the unsaturated hydraulic conductivity of the sub-biomat zone, using the measured infiltration rate at steady state as the matching $K$ factor. The Campbell model is represented as:

$$
K=K_{S}\left(\frac{\psi_{e}}{\psi}\right)^{2+3 / b}
$$


where $\Psi_{\mathrm{e}}$ is the air-entry potential of the soil $(\mathrm{m})$, and $b$ is the slope of the $\Psi(\theta)$ relationship (Campbell 1974).

\subsection{Statistical analysis}

One-way analysis of variance (ANOVA) was used to determine the statistical significance of the measured infiltration rates through the biomat zone, as well as the biomat zone properties (resistance, hydraulic conductivity, thickness). Statistically significant differences are reported when $\mathrm{P}<0.05$. All analyses were performed using Minitab Student Release v14 for Windows ${ }^{\circledR}$ (Minitab Inc., 2003).

\section{Results and discussion}

\subsection{Biomat zone development}

Over the 470 day (16 month) period of STE application, biomat zones developed in all treatment columns. A summary of some physical characteristics of the soil columns after 300 days of operation, where steady-state conditions were occurring, is presented in Table 3 . The biomat zone consisted of a discrete layer of solids that had accumulated on the soil surface and in the interstices of the gravel and surface soil.

\section{Table 3}

Selected biomat properties of treatment columns taken during steady-state operation (300-470 days). Mean values within a column followed by the same letter (lower case) are not significantly different at a 95\% confidence interval. 


\begin{tabular}{|c|c|c|c|c|c|c|}
\hline Soil & $\begin{array}{c}\text { Ks Soil } \\
\text { (initial) } \\
(\mathrm{m} / \mathrm{d})\end{array}$ & $\begin{array}{c}\text { Thickness } \\
\left(Z_{b}\right) \\
(\mathrm{m})\end{array}$ & $\begin{array}{c}\text { Hydraulic } \\
\text { conductivity } \\
\left(K_{b}\right) \\
(\mathrm{m} / \mathrm{d})\end{array}$ & $\begin{array}{c}\text { Resistance } \\
\qquad\left(R_{b}\right) \\
\text { (days) }\end{array}$ & $\begin{array}{l}\text { Infiltration } \\
\text { rate } \\
(\mathrm{m} / \mathrm{d})\end{array}$ & $\begin{array}{c}\text { Total STE } \\
\text { load per } \\
\text { column } \\
(\mathrm{L})\end{array}$ \\
\hline Sand & $24.7^{\mathrm{a}}$ & $0.023^{\mathrm{a}}$ & $0.0065^{\mathrm{a}}$ & $38^{\mathrm{a}}$ & $0.0085^{\mathrm{ab}}$ & $136^{\mathrm{a}}$ \\
\hline $\mathrm{CV}^{\mathrm{A}}$ & 0.1 & 0.1 & 1.0 & 0.53 & $\begin{array}{c}1.0 \\
8.5 \mathrm{~L} / \mathrm{m}^{2} / \mathrm{d}^{\mathrm{B}}\end{array}$ & 0.09 \\
\hline Oxisol & $7.3^{\mathrm{b}}$ & $0.021^{\mathrm{a}}$ & $0.0021^{\mathrm{b}}$ & $39^{\mathrm{a}}$ & $0.0065^{\mathrm{bc}}$ & $111^{\mathrm{a}}$ \\
\hline $\mathrm{CV}$ & 0.47 & 0.08 & 2.3 & 0.52 & $\begin{array}{c}1.1 \\
6.5 \mathrm{~L} / \mathrm{m}^{2} / \mathrm{d}\end{array}$ & 0.1 \\
\hline Vertisol & $0.23^{c}$ & $0.0045^{b}$ & $0.0008^{b}$ & $27^{\mathrm{a}}$ & $0.0028^{c}$ & $35^{b}$ \\
\hline CV & 0.04 & 0.47 & 3.2 & 0.73 & $\begin{array}{c}0.67 \\
2.8 \mathrm{~L} / \mathrm{m}^{2} / \mathrm{d}\end{array}$ & 0.05 \\
\hline
\end{tabular}

${ }^{\mathrm{A}}$ Coefficient of variation $=$ standard deviation expressed as a fraction of the mean

B Equivalent design loading rate

A zone of discoloured soil which extended into the soil to an average depth of 5 to $10 \mathrm{~mm}$, was observed after several weeks of operation. Initially, when all columns were receiving daily STE applications, the rate of biomat growth was similar for all three soils. The variability in measured properties within each soil treatment is unlikely to be a result of the packing procedures, due to the close similarities in soil column bulk densities for each soil type (standard deviation $<5 \%$ of the mean). Similarly, the average volume of STE applied to each soil type yielded a low variation (standard deviation $<1 \%$ of mean). Thus, despite the apparent homogeneity of the soil columns, the variation observed may reflect the heterogeneity of the biomat / soil interface after long-term application of STE. It is also probable that such fluctuations in biomat / soil properties would occur in undisturbed soils.

Mean $K_{b}$ values were significantly $(p<0.05)$ higher in the sand, whilst mean $Z_{b}$ values were significantly lower $(p<0.05)$ in the Vertisol. Mean $R_{b}$ was not significantly different $(p>0.05)$ similar for the sand (38 d), and Oxisol (39 d) and Vertisol (27 d) (Table 3). Lower $Z_{b} R_{b}$ values 
for the Vertisol are not unexpected as these parameters appears to be directly related to the accumulation of TSS and $\mathrm{BOD}_{5}$, i.e. the organic loading into the columns (Siegrist and Boyle, 1987). As the Vertisol received less STE due to its lower permeability, the average cumulative organic loading ( $\mathrm{BOD}_{5}$ and TSS) was substantially lower, compared with the sand and the Oxisol.

Other studies have calculated $R_{b}$ values from experimental datasets. Bouma (1975) calculated $R_{b}$ values from estimated biomat thickness and measured soil moisture potentials. The $R_{b}$ values ranged from 5 to 7 days for sand, 52 to 73 days for silty loam, and 20 to 115 days for clay soils (Bouma, 1975). These values suggest that biomat zones in coarse-grained soils are of a low resistance. Research presented here has shown the opposite effect; as the sand developed thicker, more resistance biomat zones than the Vertisol. This result will be discussed later in the paper. Kristiansen (1981) calculated $R_{b}$ in sand columns of 4, 5.5 and 35 days using the same approach as Bouma (1975). Temperature differences were attributed to the variation in $R_{b}$ values. Recent work by Beach et al. (2005) calculated $K_{b} / Z_{b}$ values for sand columns which were equivalent to $R_{b}$ values ranging from 14 to 50 days. The large variation in $R_{b}$ values reported may reflect the experimental conditions and the method of $R_{b}$ calculation. Nonetheless, a commonality in reported $R_{b}$ values, including results from this paper, is the importance of $R_{b}$ in regulating flow into soils.

In addition to higher loading rates, greater penetration of clogging within soil interstices of the sand and Oxisol effectively produced a thicker biomat. The penetration of bacteria and fine 
organic and inorganic residues into the macropores of permeable soils is likely to be greater than in the finer pores of the Vertisol (Kropf et al., 1977; Vandevivere and Baveye, 1992).
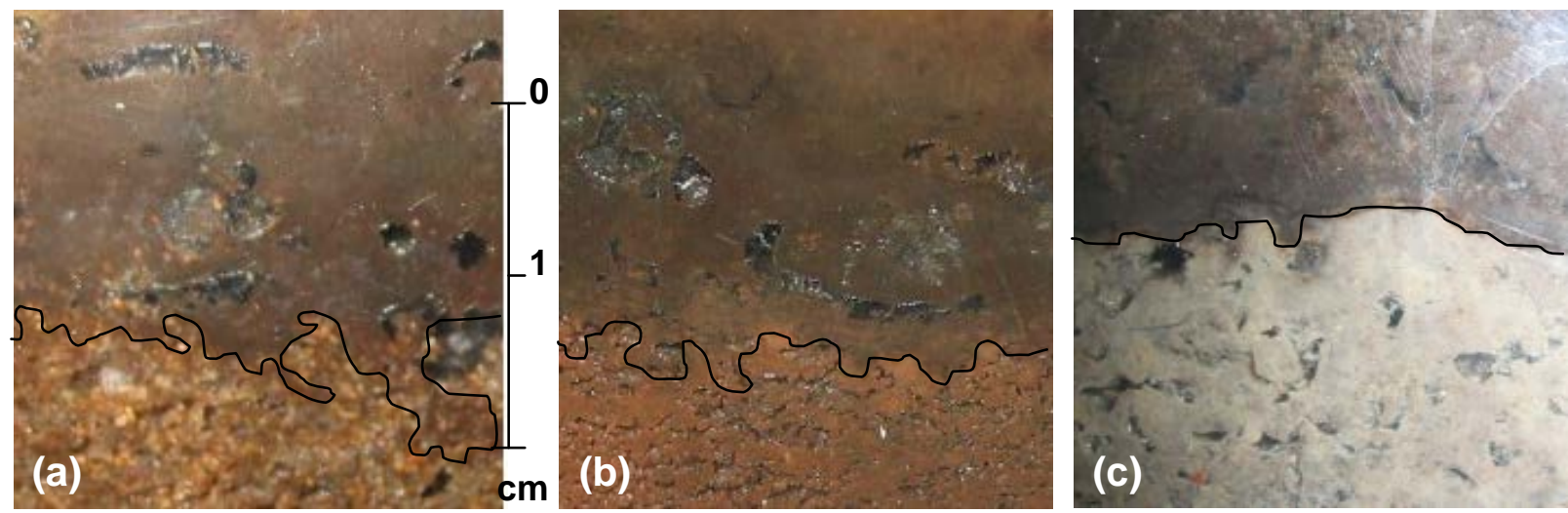

Plate 1. Developed biomat zone after one year of septic tank effluent application on sand (a), Oxisol (b), Vertisol (c). The lines indicates approximate delineation between the biomat zone and soil.

A photograph of each biomat zone is provided in Plate 1, showing fingering of organic particulates into the larger pores of the sand, and to a lesser extent the Oxisol. Thus, for these porous soils, the biomat is more appropriately considered a 'zone' rather than a discrete layer. In comparison, the biomat / soil interface in the Vertisol is much more distinct.

\subsection{Effect of biomat resistance on LTAR}

Infiltration rates through the biomat zone reduced over time with a concomitant increase in biomat resistance (Fig. 4). The initially uniform soil profile observed at the commencement of the experiment gradually changed to a layered heterogenous profile of low hydraulic conductivity. Two main infiltration states occurred in the treatment columns during the formation of this heterogenous zone. Initially, as the biomat zone developed in the first 100 
days of operation, an increase in $R_{b}$ and a concomitant decrease in infiltration rates occurred (Fig. 4).
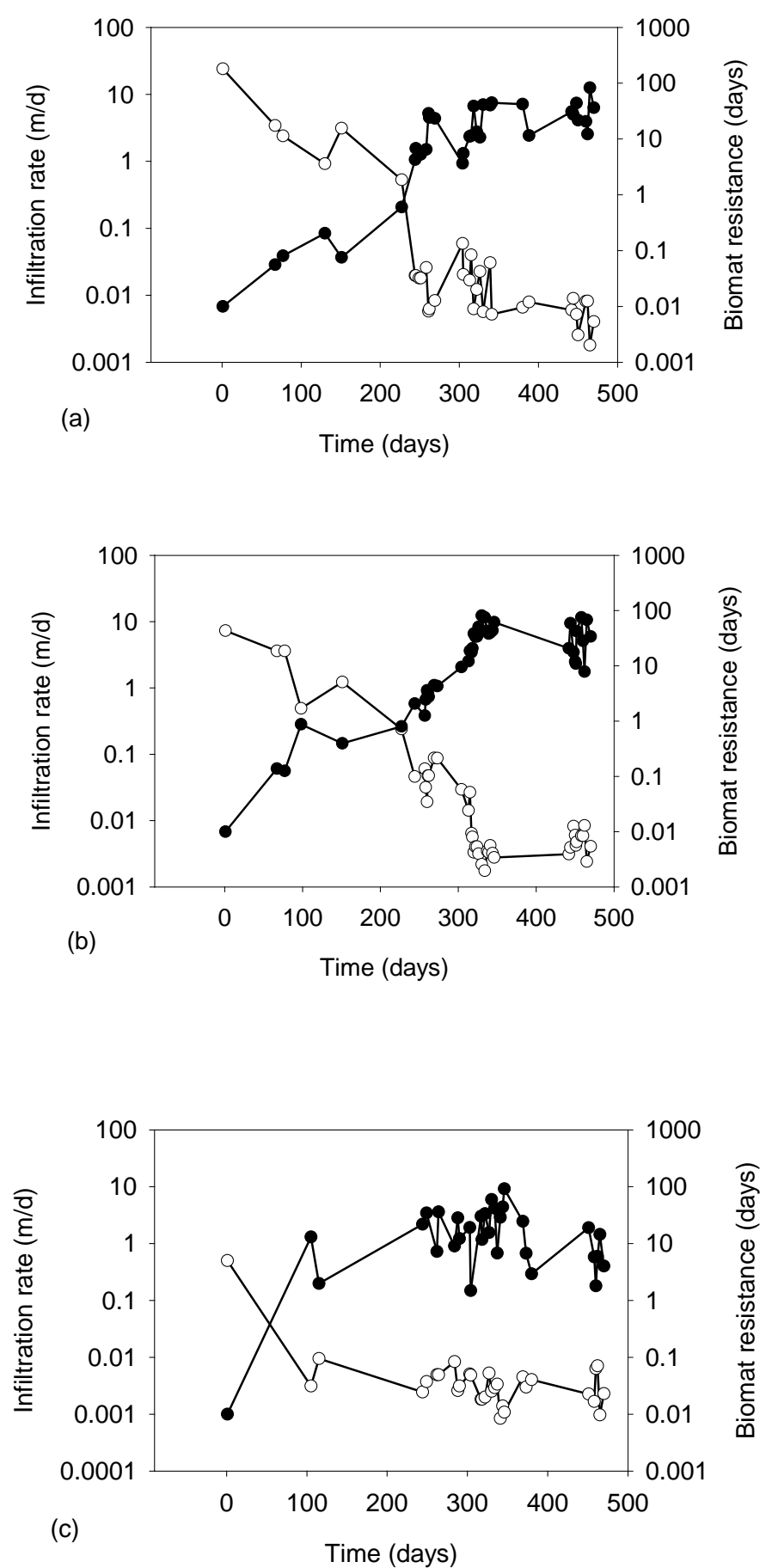
Fig. 4 Changes in average infiltration rates over time showing the relationship between high resistance and low infiltration rates for (a) sand, (b) Oxisol, and (c) Vertisol

In this phase, continuous ponding was not observed and matric potentials fluctuated during the period between STE applications. The soil profile remained more or less uniform throughout this period.

As the biomat zones matured and $R_{b}$ increased, the flow regime into the biomat and sub-biomat zone changed from transient to continuous ponding. In this phase (> 100 days), a steady-state infiltration rate (Fig. 4) and matric profile were measured. The perturbations around the steady state mean infiltration rate during this period may be explained by a variability in biomat resistance resulting from disturbance to the biomat. Bubbles forming under and above the biomat were observed throughout the experiment. These were a possible result of methanogensis, due to the anaerobic conditions prevailing in the upper part of the columns (Baveye et al., 1998). During the experiment, it was observed that the release of these bubbles to the atmosphere would often result in fissures in the biomat. These fissures were likely to have facilitated greater flow of effluent through the biomat zone, producing an increased level of variability over time in the data set seen in Fig. 4. This phenomena has been reported elsewhere under similar experimental conditions (Kristiansen, 1981; Baveye et al., 1998; Seki et al., 1998).

Averaged after 300 days of operation, LTAR (m/d) through the biomat at steady-state were 0.0085 (sand), 0.0065 (Oxisol) and 0.0028 (Vertisol) (Table 3). That is a 2 to 3 log reduction 
from the initial $K_{s}$ in the Vertisol and Oxisol, and a 4 log reduction in the sand. The average LTAR in the Vertisol was significantly lower $(p<0.05)$ than the LTAR in the other soils. However, the initial $K_{s}$ of the Vertisol was also significantly lower $(p<0.05)$, suggesting that the presence of the biomat had less effect on LTAR in this inherently low permeability soil, compared with the other soils of high $K_{s}$. The marked effect of the biomat on LTAR has been observed in other studies, particularly in permeable soils (Orlob and Butler, 1955; Kropf et al., 1977; Siegrist et al., 1991). Typical infiltration rate reductions of $>75 \%$ of the original soil $K_{s}$ have been reported (Jones and Taylor, 1965; Bouma, 1975; Kropf et al., 1977; Siegrist and Boyle, 1987; Rainwater et al., 2005) Although the sand and Oxisol received larger volumes of STE (Table 3), thus allowing greater biomat development (and resistance), steady-state infiltration rates occurred much later into the experiment than for the Vertisol. This is seen in Fig. 4 where the time taken for the Vertisol to reach a steady infiltration rate is about 100 days compared with around 300 days for the sand and Oxisol.

Biological effects of clogging were not evident in control columns. Infiltration rates in sand columns remained generally constant throughout, however the Oxisol and Vertisol showed an early decrease in infiltration rate (Fig. 5). A key purpose of the control columns was to help identify whether infiltration rate decrease was a result of abiotic reactions (e.g. swelling and dispersion of clay particles) caused by the sodium content of the STE. If abiotic reactions were a factor in infiltration rate decrease, this should be reflected in a similar pattern in the control columns. Although infiltration rates did decrease in the Oxisol and Vertisol control columns shown in Fig. 5, this decrease could not readily be attributed to chemical reactions. 


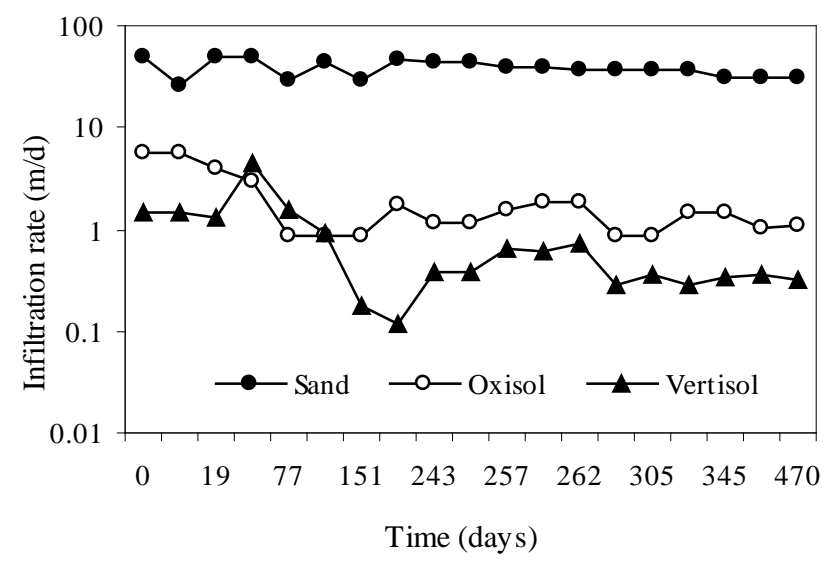

Fig. 5 Infiltration rates for control soil columns

The low SAR (average 1.2) and elevated EC (average $3.8 \mathrm{dS} / \mathrm{m}$ ) of the STE, combined with the low exchangeable sodium percentage for both the Oxisol (1.3\%) and Vertisol $(<1 \%)$, suggested that dispersion was unlikely to be a major factor in infiltration rate decrease in either soil (Rengasamy and Olsson, 1993; Patterson, 1994). In the Vertisol, a smectite clay, overburden potential and swelling in the upper part of the profile was likely to result in the reduction in infiltration rates (Bridge and Collis-George, 1973). In the Oxisol, consolidation and some swelling would have contributed to infiltration rate decrease.

\subsection{Effect of sub - biomat unsaturated soil hydraulic characteristics on LTAR}

Although unsaturated conditions were maintained throughout the columns as a result of impeded flow through the biomats, the columns remained close to saturation. A narrow range of average matric potentials was observed across soil types (Fig. 6). In the Oxisol and sand columns, matric potentials from all tensiometers ranged between $-0.15 \mathrm{~m}$ to $-0.21 \mathrm{~m}$ after 300 days. 

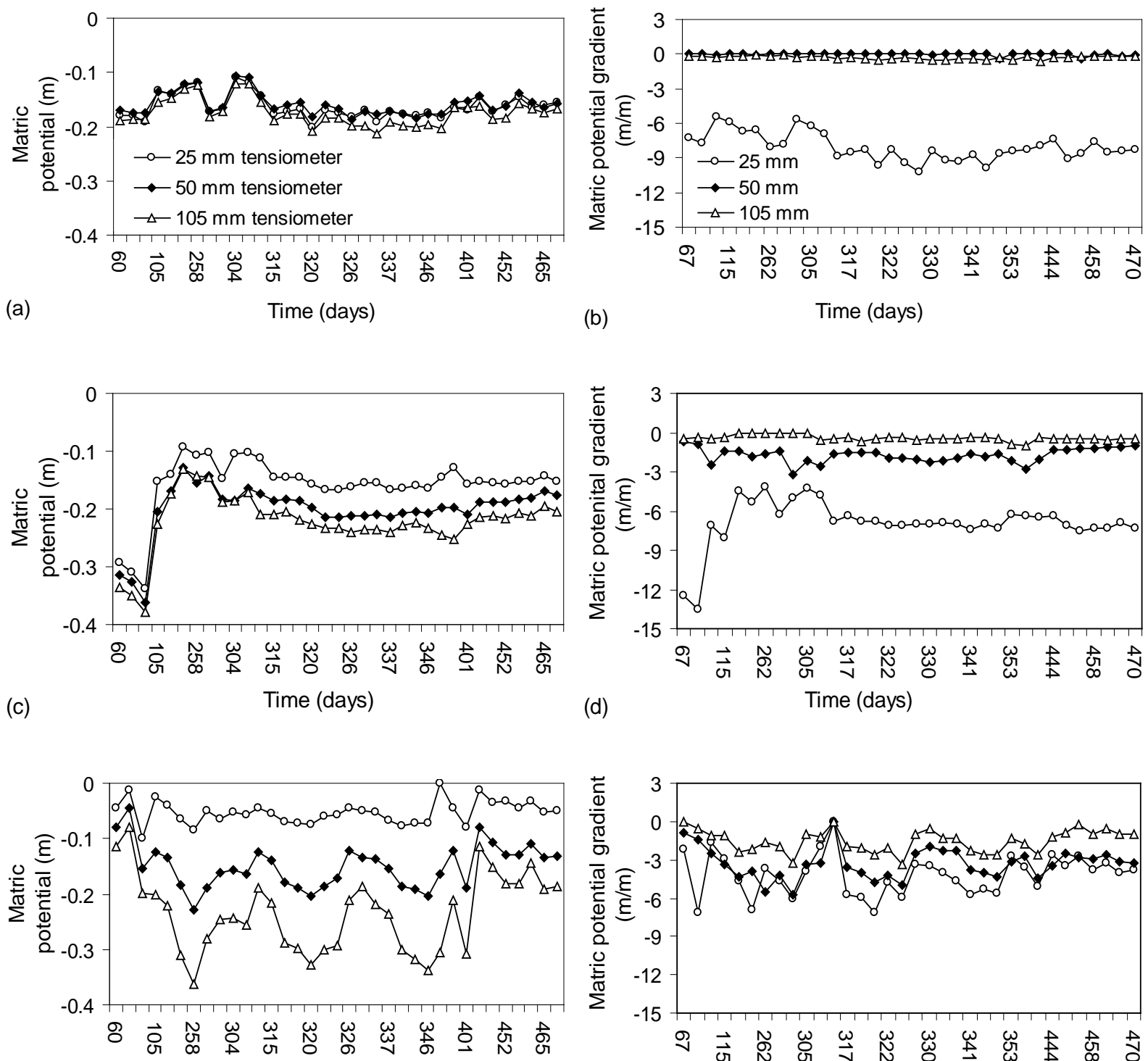

(e)

Time (days)

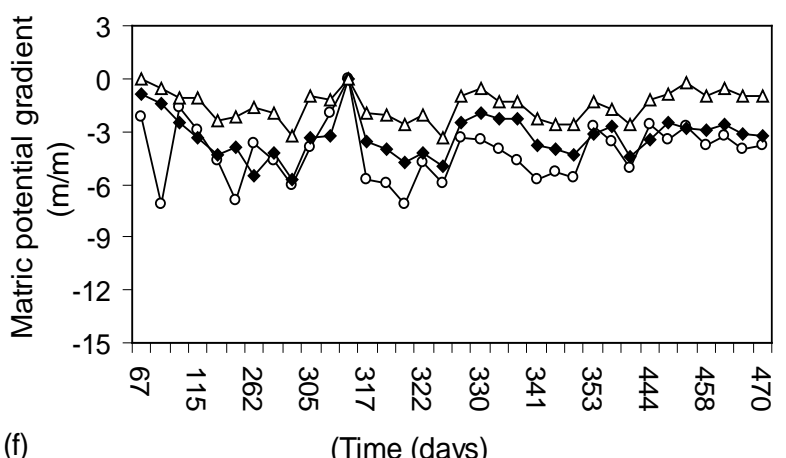

Fig. 6 Average soil matric potentials and total potential gradients at depths of $25 \mathrm{~mm}, 50 \mathrm{~mm}$ and $105 \mathrm{~mm}$ below the biomat zone in: sand (a,b), Oxisol (c,d) and Vertisol (e,f) columns.

In the Vertisol columns the matric potentials ranged from -0.04 to $-0.3 \mathrm{~m}$. Although not extensively reported, other soil column studies have been reported to have a similar sub-biomat zone potentials, ranging between $-0.12 \mathrm{~m}$ to $-0.28 \mathrm{~m}$ (Daniel and Bouma, 1974). Matric gradients, calculated from change in matric potentials between each tensiometer, are presented 
in Fig. 6. For all soils, matric potential gradients ranged from -3 to -13 between the ponded biomat (positive pressure head) and the zone immediately below the biomat at the first (25 $\mathrm{mm}$ ) tensiometer (negative pressure) (Fig. 6).

At steady-state infiltration into a crust-topped soil, hydraulic head gradients in the sub-crust soil will approach unity resulting in flow from gravitational forces only (Hillel and Gardner, 1969; Bouma, 1975). Therefore matric gradients approaching zero should be observed, as was in the case in the sand and in the lowest tensiometer in the Oxisol. Higher gradients were recorded below the biomat between the first and second tensiometers in the Oxisol. This may be an indication of deteriorating soil structure and consolidation of the soil, or possibly an effect of the biomat zone extending more deeply than apparent from the visual inspection afforded by the perspex windows. The different behaviour of the Vertisol compared to the other two soils was possibly related to ongoing, slow swelling and associated changes in overburden potentials.

Equation 1 describes the mechanism of 'self adjusting flow' whereby the biomat properties and the sub-biomat soil $K(\Psi)$ create a gradient across the biomat zone that allows for a state of equal flux through the both the biomat and underlying soil zones. Adjustment in flow is triggered by hydraulic gradient changes across the biomat, which are in turn, influenced by the unsaturated soil hydraulic characteristics. During unsaturated flow, there is less connectivity between the conducting pores in coarse-textured soils. Conversely, in fine-grained soils that consist mainly of smaller pores, connectivity during unsaturated flow is much greater, thus unsaturated flow in clays can be higher than in sands. This concept is illustrated in Fig. 7, 
where the $K(\Psi)$ curves for each soil were derived using Campbell's (1974) method. The sand and Oxisol hydraulic conductivity decreases sharply under low matric potentials, whereas the Vertisol hydraulic conductivity tapers off much more gradually. The $K$ values begin to converge for all soils around matric potentials of -0.2 to $-0.3 \mathrm{~m}$, which generally falls into the range of potentials observed at steady-state during operation. This is reflected by the similar LTAR values ( 0.0028 to $0085 \mathrm{~m} / \mathrm{d})$ measured, and illustrates the influence of not only $R_{b}$, but the unsaturated soil hydraulic conductivity characteristics on LTAR.

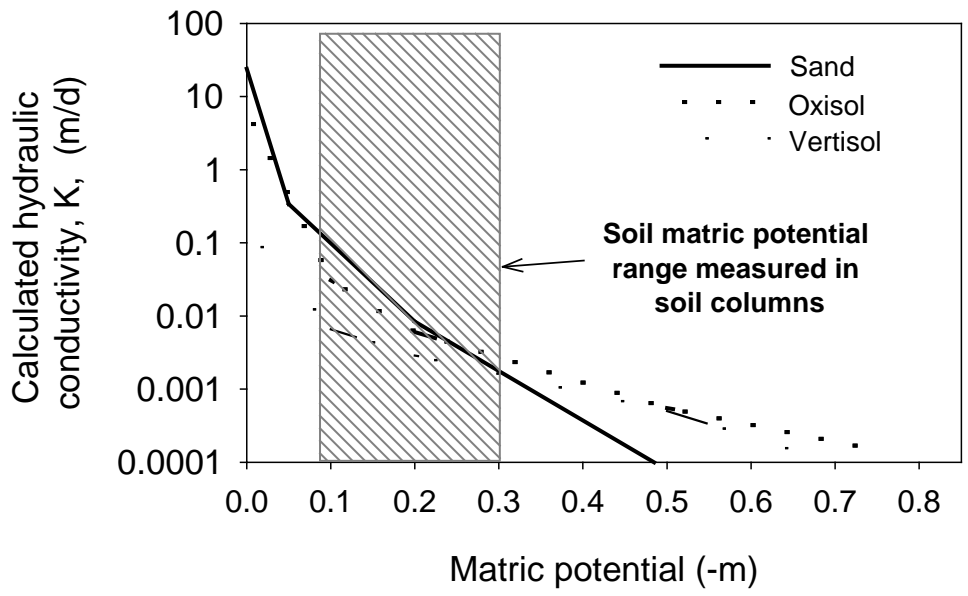

Fig 7 Predicted hydraulic conductivity curves for the soils using Campbell's equation (1974)

\subsection{Cumulative organic loading rates}

The relationship between cumulative organic loading rate and the extent of biomat development (i.e resistance) for the three soils is shown in Fig. 8. A stronger, although not unique, relationship is evident in the high $K_{s}$ soils with $\mathrm{R}^{2}$ values $>0.78$. The average equivalent organic loading rates $\left(\mathrm{kg} / \mathrm{m}^{2} / \mathrm{d}\right)$ for sand and Oxisol columns were 2 to 3 times greater than that of the Vertisol columns (Fig. 9). Therefore the more permeable soils had 
greater potential to receive larger volumes of STE for longer periods, thus facilitating a higher degree of biomat development (e.g. $Z_{b}$ and $R_{b}$ ).

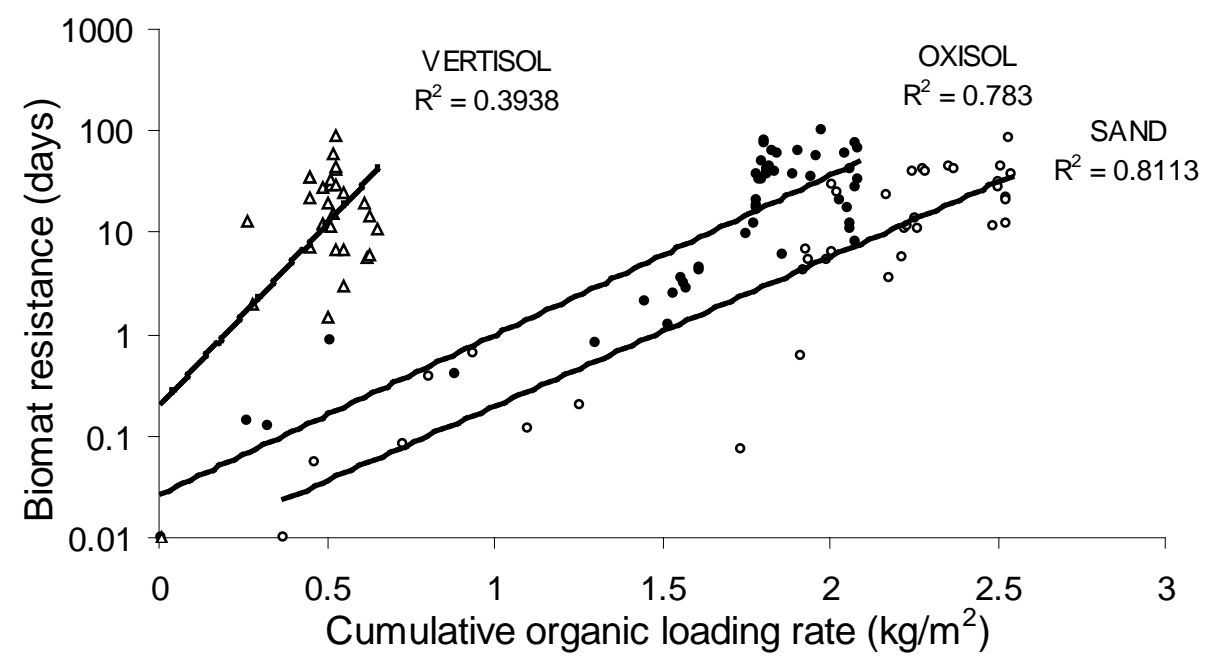

Fig. 8 Relationship between cumulative organic (BOD $\left.{ }_{5}+\mathrm{TSS}\right)$ loading rate and biomat resistance
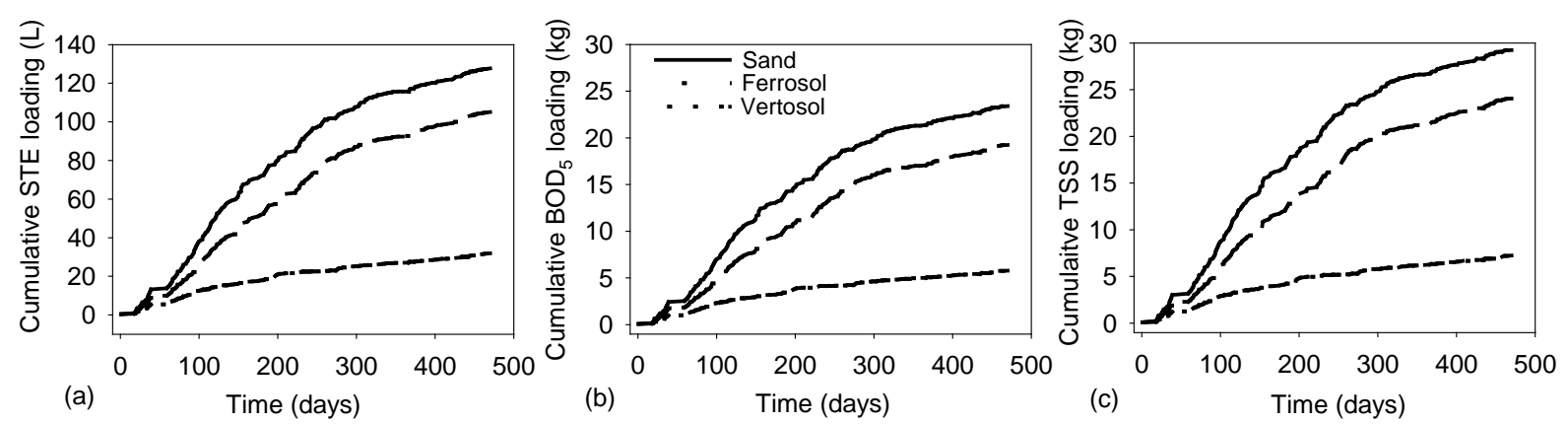

Fig. 9 Average cumulative loadings for (a) STE, (b) BOD 5 and (c) TSS

This would also be expected to occur in field conditions, for SAS constructed in permeable soils. Here, trenches are sized to accept higher effluent loads per unit trench area, and hence would be likely to develop more resistant biomats, and at a faster rate, than SAS located in less 
permeable soils. The capacity for soils of high $K_{s}$ to accept higher organic loading rates is implicitly built into the LTAR recommended in trench sizing guidelines (e.g. Standards Australia, 1994; USEPA, 2002). The higher the $K_{s}$, the smaller the trench length required, as the soils of high $K_{s}$ can accept greater organic loadings over a smaller infiltrative surface area. Therefore in the field, hydraulic and organic loading into high $K_{s}$ soils is greater than loading into low $K_{s}$ soils.

Using cumulative organic loading rates $\left(\mathrm{BOD}_{5}+\mathrm{TSS}\right)$, Siegrist and Boyle (1987) developed a logistic model formulated from a sigmoidal curve function of infiltration rate over time:

$$
I R_{t}=241 * \frac{\left\{\exp \left[2.63-5.70(t B O D)+41.08(T S S)-0.048\left(t B O D^{*} T S S\right)\right]\right\}}{\{1+\exp [2.63-5.70(t B O D)+41.08(T S S)-0.048(t B O D * T S S)]\}}
$$

where $I R_{t}$ is the infiltration rate at time, $\mathrm{t}(\mathrm{cm} / \mathrm{d})$, tBOD is the cumulative density loadings $\left(\mathrm{kg} / \mathrm{m}^{2}\right)$ of total BOD (carbonaceous BOD and nitrogenous BOD), and TSS is total suspended solids $\left(\mathrm{kg} / \mathrm{m}^{2}\right)$. The Siegrist and Boyle (1987) model was used to predict infiltration rate behaviour over time using the cumulative organic loading rates presented in this paper (Fig. 10). An exponential function, derived specifically from the experimental data, was also used to predict infiltration rate response to organic loading rate and is also presented in Fig 10:

$$
L T A R=a^{*} \exp (-b(\Sigma B O D+T S S))
$$

where $a$ and $b$ are constants. 


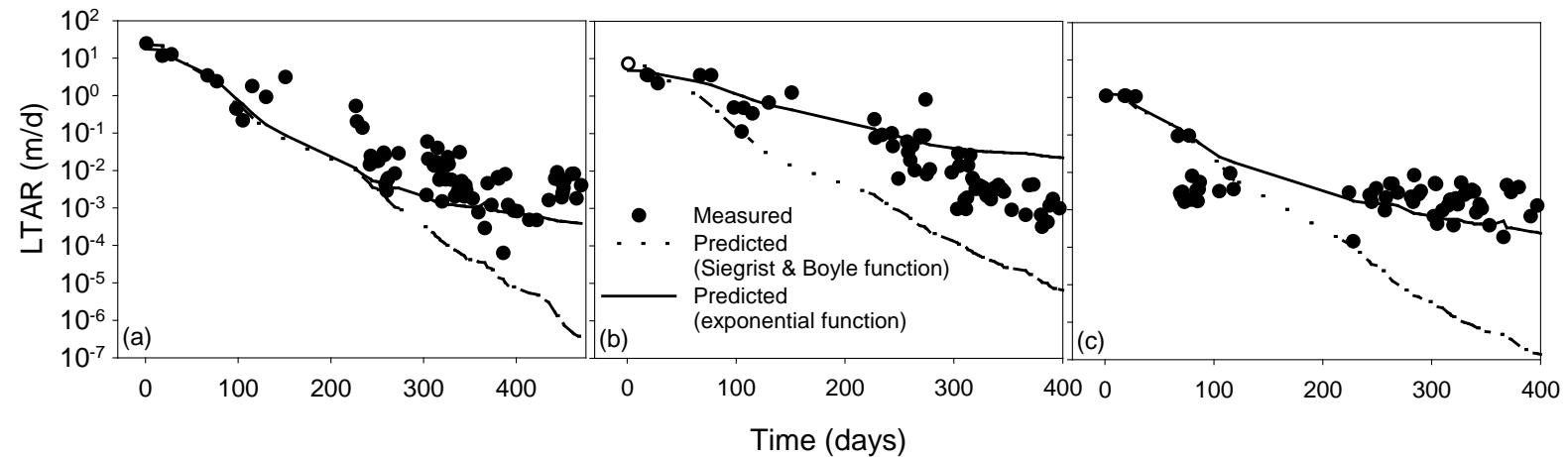

Fig. 10 Comparison of measured and predicted LTAR over time using the Siegrist and Boyle (1987) model and an exponential function $\left(\mathrm{R}^{2}=0.89\right.$ sand, 0.82 Oxisol and 0.92 Vertisol) generated from experimental data for (a) sand, (b) Oxisol and (c) Vertisol.

A generally poor fit was observed using the Siegrist and Boyle (1987) model. This model suggested that, ultimately, the LTAR would approach zero with continual effluent loading. Closer fits were achieved using the exponential function derived from the dataset, although these curves did not simulate the trend toward steady-state infiltration in the Vertisol. Results from Fig. 10 indicate that the applicability of these types of models is limited to the specific set of experimental design conditions and wastewater quality associated with the particular study. Consequently, they are unlikely to be generally applicable reproducible for estimating biomat development. 


\subsection{Soil hydraulic properties and LTAR}

Several conclusions relating to the importance of soil hydraulic properties in SAS can be drawn from the results. Firstly, a marked reduction in infiltration rates is inevitable in SAS, regardless of soil type, assuming that the loading of STE is more or less constant. In this respect, intermittent dosing of STE has been shown to generate biomats of lower resistance than gravity distribution of STE (Beach et al., 2005). Secondly, and again regardless of soil texture, the resultant LTAR will typically fall within a narrow range of values (e.g. within 1 log after $>200$ to 300 days of STE application) (Fig 4). These results suggest that the biomat zone was the governing factor for flow through the columns, irrespective of the underlying soil type, suggesting that soil texture is not an important factor in determining the LTAR in SAS, yet we know empirically that this is not the case.

Thirdly, evolution of LTAR in the soil columns appeared to occur in two processes, with both processes being dependent on soil hydraulic properties to some degree. The first process was the establishment of the biomat zone, which appeared largely a function of cumulative organic loading rates. In the sand and Oxisol, the initially high $K_{s}$ facilitated higher hydraulic loading rates, and hence higher organic loading rates (Fig. 4), and this subsequently produced thicker biomats with higher $R_{b}$ values. The second process relates to the development of the LTAR which is a factor of $R_{b}$ and the $\mathrm{K}(\Psi)$ of the sub-biomat soil. These two factors interacted to develop hydraulic gradients across the biomat zone that allowed a steady-state flow rate (LTAR) to develop over time as shown in Fig. 4. 
Finally, in soils of very low permeability such as the Vertisol, the LTAR may be influenced more by the inherently low $K_{s}$, rather than $R_{b}$. In this respect, $R_{b}$ in low permeable soils is selflimiting as the reduced infiltration rate of the soil dictates a lower organic loading rate and reduced thickness of the biomat zone.

Once a steady-state infiltration rate is reached in a SAS, effluent should theoretically continue to infiltrate at the LTAR of the soil. In extreme conditions such as heavy rainfall and / or episodic excessive household water use, where the hydraulic loading into the trench exceeds the LTAR, exfiltration through the sidewalls above the biomat may occur (Rutledge et al., 1993). In these conditions, the soil $K_{s}$ would play an important role in determining the rate of sidewall discharge and thus the buffering capacity of the trench to prevent surface surcharging of effluent. In permeable soils the area of sidewall that has no impedance from the biomat (the exfiltration zone) is hypothesised to be an important absorption pathway for effluent under extreme conditions (Beal et al., 2004). Soil properties will clearly be important in these conditions in determining the likelihood of surface failure of trenches under peak hydraulic loads.

\section{Conclusions}

STE was applied to three soils of contrasting textures to observe the biomat zone development and the influence of the biomat zone on LTAR. Steady-state infiltration rates were reached after around 300 days. A four order of magnitude variation in initial $K_{s}$ between the soils reduced to a one order of magnitude variation in LTAR. LTAR ranged from $0.0028 \mathrm{~m} / \mathrm{d}$ in the clay soil to $0.0085 \mathrm{~m} / \mathrm{d}$ in the sand. There was no significant differences in $R_{b}$ between soil 
textures. A relationship between $R_{b}$ and organic loading rate was found in all soils, however this relationship did not appear to be unique to the high $K_{s}$ soils.

Results from the soil column experiments indicate that soil hydraulic properties influenced the rate and extent of biomat development, but once the biomat was established, the LTAR was dictated by the resistance of the biomat and the unsaturated flow regime induced by the biomat. Unsaturated flow rates were influenced by the $K(\Psi)$ function of each soil. Therefore, whilst the initial soil $K_{s}$ is likely to be important in the establishment of the biomat zone in a trench, the subsequent development of the LTAR is a function of the unsaturated hydraulic conductivity, not the saturated hydraulic conductivity of a soil. Given this, the use of $K_{s}$ as the key soil characteristic to size SAS trench length (e.g. Standards Australia, 1994; USEPA, 2002) is questioned. However, soil $K_{s}$ may play a role in minimising surface surcharging in permeable soils where sidewall exfiltration above the biomat zone is a key pathway in extreme hydraulic loading into a trench.

\section{Acknowledgements}

The authors thank the Chamberlain family for access to their septic absorption system. We also acknowledge the support of the Coastal CRC.

\section{References}

American Public Health Association (1998) Standard methods for the examination of water and wastewater, American Public Health Association, 1998.

Bancole, A., Brissaud, F. and Gnagne, T. (2003) Oxidation processes and clogging in intermittent unsaturated infiltration. Water Science and Technology 48(11-12), 139146. 
Baveye, P., Vandevivere, P., Hoyle, B.L., DeLeo, P.C. and de Lozada, D.S. (1998)

Environmental impact and mechanisms of the biological clogging of saturated soils and aquifer materials. Critical Reviews in Environmental Science and Technology 28(2), 123-191.

Beach, D., McCray, J., Lowe, K. and Siegrist, R. (2005) Temporal changes in hydraulic conductivity of sand porous media biofilters during wastewater infiltration due to biomat formation. Journal of Hydrology 311, 230-243.

Beal, C.D., Gardner, E.A., Menzies, N.W., Rassam, D.W. and Vieritz, A.M. (2004) Prediction of steady-state flux through variably saturated zones within a septic absorption trench. Proceedings of the International Soil Science Conference 2004, 5 - 9 December 2004, Sydney, Australia.

Beal, C.D., Gardner, E.A. and Menzies, N.W. (2005a) Process, performance and pollution potential: A review of septic tank - soil absorption systems. Australian journal of soil research 43(7), 781- 802.

Beal, C.D., Gardner, E.A., Christiansen, C. and Beavers, P. (2005b) A review of on-site wastewater management practices in south-east Queensland. Water 32 (4)(4), 69-72.

Blake, G.R. and Hartge, K.H. (1986) Methods of soil analyses, Part 1 - Physical and mineralogical methods. Klute, A. (ed), American Society of Agronomy / Soil Science Society of America: Madison.

Bouma, J. (1975) Unsaturated flow during soil treatment of septic tank effluent. Journal of Environmental Engineering (ASCE) 101(EE6), 967-983.

Bridge, B.J. and Collis-George, N. (1973) An experimental study of vertical infiltration into a structurally unstable swelling soil, with particular reference to the infiltration throttle. Australian journal of soil research 11(2), 121-132.

Campbell, G.S. (1974) A simple method for determining unsaturated conductivity from moisture retention data. Soil Science 117(6), 311-314.

Charles, K.J., Ashbolt, N.J., Roser, D.J., McGuinness, R. and Deere, D.A. (2004) Effluent quality from 200 on-site sewage systems: Design values for guidelines.

Crites, R.W. and Tchobanoglous, G. (1998) Small and decentralized wastewater management systems, WCB/McGraw-Hill.

Daniel, T.C. and Bouma, J. (1974) Column studies of soil clogging in a slowly permeable soil as a function of effluent quality. Journal of Environmental Quality 3(4), 321-326.

Gardner, T., Geary, P. and Gordon, I. (1997) Ecological sustainability and on-site effluent treatment systems. Australian journal of environmental management 4(2), 144-156.

Gee, G.W. and Bauder, J.W. (1986) Methods of soil analyses, Part 1 - Physical and mineralogical methods. Klute, A. (ed), American Society of Agronomy / Soil Science Society of America: Madison.

Hillel, D. and Gardner, W.R. (1969) Steady infiltration into crust-topped profiles. Soil Science 108(2), 137-142.

Isbell, R.F. (1998) The Australian Soil Classification, CSIRO Publishing, Collingwood Victoria, Australia. 143p.

Jelliffe, P.A. (1994) A study of the performance of on-site treatment and disposal systems in Maroochy Shire, Jelliffe Environmental Pty Ltd.

Jones, J.H. and Taylor, G.S. (1965) Septic tank effluent percolation through sands under laboratory conditions. Soil Science 99(5), 301-309. 
Klute, A. (1986) Methods of soil analyses, Part 1 - Physical and mineralogical methods. Klute, A. (ed), American Society of Agronomy / Soil Science Society of America: Madison.

Kristiansen, R. (1981) Sand-filter trenches for purification of septic tank effluent: I. The clogging mechanism and soil physical environment. Journal of Environmental Quality 10(3), 353-357.

Kropf, F.W., Laak, R. and Healy, K.A. (1977) Equilibrium operation of subsurface absorption systems. Journal of Water Pollution Control Federation 49(9), 2007-2016.

Laak, R. (ed) (1986) Wastewater engineering design for unsewered areas, Technomic Publishing Co. Inc.

McKenzie, N., Coughlan, K. and Cresswell, H. (2002) Soil physical measurement and interpretation for land evaluation, CSIRO Publishing, Australia.

Minitab Inc. (2003) MINITAB Statistical Software, Release 14 for Windows, State College, Pennsylvania. MINITAB ${ }^{\circledR}$ is a registered trademark of Minitab Inc.

Orlob, G.T. and Butler, R.G. (1955) An investigation of sewage spreading on five California soils, Sanitary Engineering Research Laboratory Technical Bulletin 12, University of California, Berkeley, CA.

Patterson, R.A. (1994) On-site treatment and disposal of septic effluent, PhD thesis. Departments of Resource Engineering and Agronomy and Soil Science. University of New England, Armidale.

Pell, M. and Nyberg, F. (1989) Infiltration of wastewater in a newly started pilot sand-filter system: I. Reduction of organic matter and phosphorus. J Environ Qual 18, 451-457.

Rainwater, K., Jackson, A., Ingram, W., Lee, C.Y., Thompson, D., Mollhagen, T., Ramsey, H. and Urban, L. (2005) Field demonstration of the combined effects of absorption and evapotranspiration on septic system drainfield capacity. Water Environment Research 77(2), 150-161.

Rawlinson, L.V. (1994) Review of on-site wastewater systems, Report prepared for Environment Protection Authority, New South Wales, Southern Tablelands Region.

Rengasamy, P. and Olsson, K. (1993) Irrigation and sodicity. Australian journal of soil research 31, 821-837.

Rutledge, E.M., Teppen, B.J., Mote, C.R. and Wolf, D.C. (1993) Designing septic tank filter fields based on effluent storage during climatic stress. J Environ Qual 22, 46-51.

Seki, K., Miyazaki, T. and Nakano, M. (1998) Effects of microorganisms on hydraulic conductivity decrease in infiltration. European Journal of Soil Science 49, 231-236.

Siegrist, R. and Boyle, W.C. (1987) Wastewater-induced soil clogging development. Journal of Environmental Engineering 113(3), 550-566.

Siegrist, R., Smed-Hildmann, R., Filip, Z.K. and Jenssen, P.D. (1991) Humic substances formation during wastewater infiltration, pp. 223-232, Proceedings of the Sixth National Symposium on Individual and Small Community Sewage Systems. ASAE; St Joseph, Chicago, IL.

Siegrist, R., McCray, J. and Lowe, K. (2004) Wastewater infiltration into soil and the effects of infiltrative surface architecture. Small Flows Quarterly 5(1), 29-39.

Standards Australia (1994) AS 1547: 1994 - Disposal systems for effluent from domestic premises, p. 43, Standards Association of Australia, NSW.

Standards Australia and Standards New Zealand (2000) AS/NZS 1547:2000 On-site domestic wastewater management, Jointly published by Standards Australia International Ltd, NSW and Standards New Zealand, Wellington. 
Stevik, T.K., Ausland, G., Jenssen, P.D. and Siegrist, R. (1999) Removal of E.coli during intermittent filtration of wastewater effluent as affected by dosing rate and media type. Water Research 33(9), 2088-2098.

USDA and NRCS (1996) Keys to soil taxonomy, United States Department of Agriculture and Natural Resources Conservation Service, Washington D.C, USA.

USEPA (2002) Onsite wastewater treatment systems manual, p. 376, Office of Research and Development, US Environmental Protection Agency EPA/625/R-00/008, February.

van Cuyk, S., Siegrist, R., Logan, A., Masson, S., Fischer, E. and Figueroa, L. (2001) Hydraulic and purification behaviours and their interactions during wastewater treatment in soil infiltration systems. Water Research 35(4), 953-964.

Vandevivere, P. and Baveye, P. (1992) Saturated hydraulic conductivity reduction caused by aerobic bacteria in sand columns. Soil Science Society of America Journal 56(1), 1-13. 